Research article

\title{
Z-CELLS AND OOGONIA/OOCYTES IN THE ADVANCED PROCESS OF AUTOPHAGY ARE THE DOMINANT ALTERED CELLS IN THE OVARIES OF HYPOTHYROID NEWBORN RATS
}

\author{
DANILOVIĆ LUKOVIĆ Jelena ${ }^{1 *}$, KORAĆ Aleksandra ${ }^{2}$, MILOŠEVIĆ Ivan ${ }^{3}$, \\ LUŽAJIĆ Tijana ${ }^{3}$, MILANOVIĆ Zorana ${ }^{3}$, KOVAČEVIĆ FILIPOVIĆ Milica ${ }^{3}$, \\ RADOVANOVIĆ Anita ${ }^{3}$
}

${ }^{1}$ State University of Novi Pazar, Department of Biomedical Sciences, Vuka Karadžića bb, 36300 Novi Pazar, Serbia; ${ }^{2}$ University of Belgrade, Center for Electron Microscopy, Faculty of Biology, Studentski trg 16, 11000 Belgrade, Serbia; ${ }^{3}$ University of Belgrade, Faculty of Veterinary Medicine, Bulevar oslobođenja 18, 11000 Belgrade, Serbia

(Received 15 November 2016, Accepted 20 January 2017)

Induced prenatal hypothyroidism in rat pups leads to accelerated primordial follicle assembly and premature follicular atresia with ovary failure. This work investigates the influence of maternal hypothyroidism induced with 6-n-propyl-2-thyouracil (PTU) on the number and morphology of oogonia/oocytes in newborn rat pups with light and transmission electron microscopy. Expression of apoptosis and autophagy markers in oogonia/oocytes were examined using immunohistochemistry. Hypothyroid newborn pups had a decreased number of mitotic and resting oogonia, while the number of altered oogonia/oocytes was increased. Ultrastructural observations revealed the increased presence of degenerated pachytene oocytes (Z-cells) and oogonia/oocytes undergoing autophagy, apoptosis and combined apoptosis and autophagy, in this group. The most abundant altered oogonia/oocytes in the hypothyroid group were those with morphological features of advanced autophagy and Z-cells. The percentage of TUNEL (terminal deoxynucleotidyl transferase dUTP nick end labeling) positive oogonia/ oocytes was significantly lower in the hypothyroid group. No significant difference was recorded in the expression of caspase-3, ATG7 and LC3 possibly reflecting that these proteins were not involved in the oogonia/oocyte alteration process during prenatal rat hypothyroidism. The obtained results indicate that developmental hypothyroidism in the offspring enhances the number of Z-cells and oogonia/oocytes altered with the advanced process of autophagy.

Key words: ATG7, caspase-3, LC3, meiosis prophase I, secondary necrosis.

\section{INTRODUCTION}

Effects of maternal hypothyroidism on offspring health are important in human [1] and veterinary medicine [2]. Previously, in the rat model, we have shown that maternal

\footnotetext{
*Corresponding author: e-mail: reginadelphy@yahoo.com
} 
hypothyroidism during pregnancy and lactation leads to premature ovarian failure of pubertal and adult offspring [3]. Histologically, more advanced activation of primary, secondary, preantral and antral follicles and their increased atresia was found [3]. Our further examination of neonatal and early infantile period in the same animal model, revealed enlarged smooth ER (sER) and altered mitochondrial morphology of oocytes forming primordial follicles without an increase in apoptotic cell markers. It could be explained by the fact that resting follicles in hypothyroid animals would enter atresia due to apoptosis but only when gonadotropins stimulate further maturation [4]. However, it is possible that oogonia/oocytes elimination in hypothyroid rat pups could be enhanced immediately after birth, i.e. in the period when damaged germ cells are physiologically eliminated. This aspect of maternal hypothyroidism has not been investigated yet.

The ovary of a newborn rat is a symbiosis of life and death because selective loss of immature oogonia/oocytes is an important mechanism for maintenance of a successful reproductive capacity in the mature age [5]. A sharp decline of oocytes number happens at meiotic prophase $I$ in rats, mice and humans [6] due to meiotic pairing anomalies [7] and recombination defects [8]. Major underlying mechanisms for oogonia/oocytes elimination are apoptosis and autophagy or the process that is a combination of both [9]. Several authors agree that in mice and rats, prenatally and at the time of birth, apoptosis is the dominant way of oocytes elimination, while autophagy takes places mostly after the fifth day postpartum [9,10]. In fact, exactly at the time of birth, autophagy is considered as an oogonia/oocyte survival program enabling ovaries to cope with a stress induced by the change of the environment and short temporary lack of nutrition [11]. In rats at the time of birth, the effect of hypothyroidism on oogonia/oocytes apoptosis and autophagy is not known.

The aim of this work was to determine the impact of maternal hypothyroidism on processes engaged in oocyte elimination in newborn pups using light and electron microscopy and immunohistochemistry (Caspase-3, TUNEL for apoptosis and ATG7, LC3 for autophagy definition).

\section{MATERIALS AND METHODS}

\section{Animals and experimental design}

Female Albino Oxford rats 3-months-old with regular 4 days cycle, were kept within the animal facility under standard conditions. Animal handling and treatment was performed with the Ethical Committee of the Faculty of Veterinary Medicine University of Belgrade approval (date: 15.05.2013., number 01-20/6) and according to the Serbian Animal Welfare Protection Law and Directive 2010/63/EU.

A female was caged with a male rat until the presence of sperm in the vaginal smears, which was considered as gestation day 0 . Pregnant females were randomly divided into two groups, each consisting of six animals. From the first day of pregnancy, treated 
dams consumed drinking water with $1.5 \mathrm{mg} / \mathrm{L}$ PTU (Sigma Chemical Co. St. Louis, MO, USA) while those in the control group were given tap water without PTU. Five female pups from each group were decapitated with surgical scissors within $24 \mathrm{~h}$ hours of delivery and blood was collected in tubes with heparin. Triiodothyronine (T3) and thyroxine (T4) concentrations in blood plasma of dams and pups were determined by RIA method using radioimmunoassay kits (INEP, Zemun, Serbia).

\section{Light microscopy}

Fixation of both thyroid gland and ovaries was performed in 10\% neutral-buffered formalin, followed by dehydration and embedding in paraffin. Every fifth section of the ovary and thyroid gland ( $5 \mu \mathrm{m}$ thickness) was stained with hematoxyline/eosin and underwent histological examination.

The number of germ cell nests (GCN) in the presumptive cortex and medulla, average number of oogonia and oocytes, and number of the following types of germinative cells: resting oogonia, oogonia undergoing mitosis, pre-diplotene and diplotene oocytes were determined in the ovaries of newborn rats as previously described [12]. Atypical oogonia and oocytes, with strongly acidophilic cytoplasm and/or intense vacuolization, often with a condensed nucleus, which could not be included in any of the above mentioned categories were counted separately.

Stereology of the thyroid gland and calculation of the activation index ( $\mathrm{Ia}$ ) was performed as described previously $[4,13]$.

\section{Electron microscopy}

Ovaries were fixed in 4\% glutaraldehyde and post-fixed in 1\% osmium tetroxide. After dehydration in a graded series of acetone, the tissue was embedded in araldite. Semithin sections were stained with toluidine blue and used to select areas of interest. Ultra-thin sections of selected areas were obtained using Leica UC6 ultramicrotome (Leica Microsystems, Wetzlar, Germany), mounted on copper grids and contrasted in uranyl acetate and lead citrate using Leica EM STAIN (Leica Microsystems). Sections were examined on a Philips CM12 transmission electron microscope (Philips/FEI, Eindhoven, Netherlands) equipped with a digital camera SIS MegaView III (Olympus Soft Imaging Solutions, Münster, Germany).

\section{Number of oogonia/oocytes morphological types on TEM}

Number of normal oogonia/oocytes, Z-cells, those undergoing autophagy, combined autophagy/apoptosis and apoptosis was determined within GCN. The number specific oogonia/oocyte type is given as percentage of total number of oogonia/ oocyte number per GCN. Electron micrographs were taken at magnification x1800 and counting was done on at least 200 oogonia/oocytes. 


\section{Immunohistochemistry protocols and examination}

Immunohistochemistry was performed on paraffin sections using anti-ATG7 (1:300) (Santa Cruz, Biotech, USA), anti-cleaved caspase-3 (1:300) (Asp 175) (Cell Signaling Technology, USA) and LC3 a/b (1:300) (Abcam, UK) antibodies. The same immunohistochemistry procedure was performed for all antibodies as described previously [4]. Rabbit Specific HRP/DAB (ABC) Detection IHC Kit (ab64261, Abcam, UK), was used for reaction visualization.

Manufacture's protocol was used to label TUNEL positive cells (FragEL DNA fragmentation Detection kit with colorimetric TdT enzyme, QIA33, Merck Millipore, Darmstadt, Germany).

\section{Evaluation of TUNEL expression}

TUNEL expression in the oogonia/oocytes of newborn rats was evaluated by counting TUNEL positive oogonia/oocytes in relation to the total number of oogonia/ oocytes per whole ovary section and was given as a percentage of total oogonia/ oocytes counted. Histology analyses were done on microscope Olympus CX43, with corresponding Olympus Digital Camera C7070.

\section{Statistical analysis}

Two independent researchers reviewed all slides two times for morphological and stereological analysis and three times for immunohistochemical evaluations. Values above and below the confidence interval (5-95\%) were excluded from further processing of results.

Statistical analysis for differences between groups were performed using Student's t-test. Results were expressed as mean \pm standard error. Levels of significance were: * $\mathrm{p}<0.05 ;{ }^{* *} \mathrm{p}<0.01 ;{ }^{* * *} \mathrm{p}<0.001$.

\section{RESULTS}

\section{Thyroid status of mothers and newborns}

Hypothyroid dams had significantly decreased T3 and T4 (Figure 1-A and B). Thyroid glands of newborn hypothyroid pups had abundant micro-follicles, mostly columnar epithelium and mitotic figures (Figure 1-C and D). In hypothyroid pups, the thyroid activation index was increased two times, T4 concentration was decreased by one third (Figure 1-E) and body mass was decreased by one sixth comparing to the controls (Figure 1-F). Otherwise, newborn pups have been normally active for that age group. 

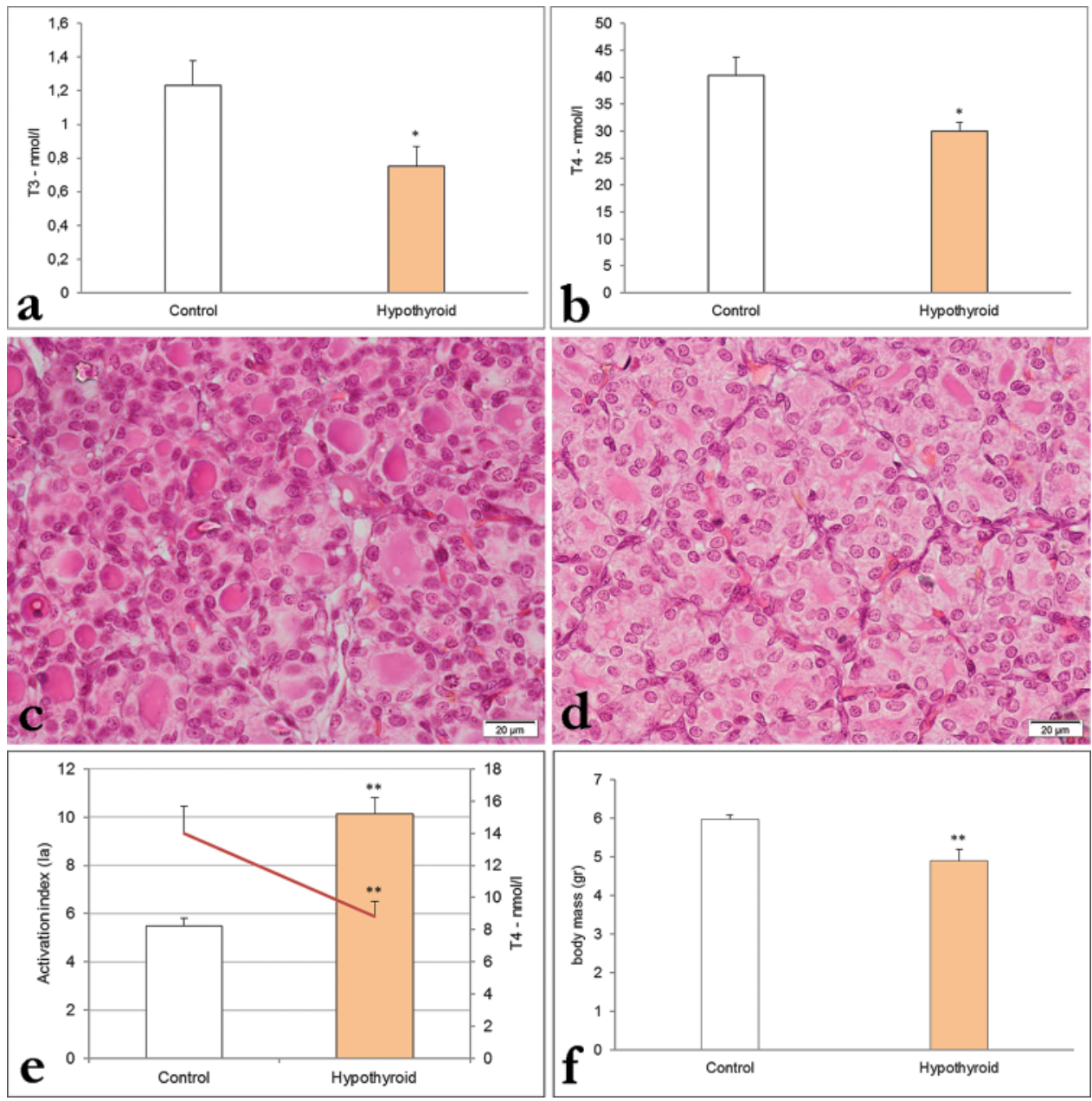

Figure 1. (A) Triiodothyronine (T3) and (B) thyroxine (T4) concentrations in the blood plasma of control and hypothyroid dams. Thyroid gland of newborn rats: (C) control and (D) hypothyroid. (E) Activation index of thyroid gland is presented with bars and thyroxine concentration in blood plasma of newborn rats of the control and hypothyroid group is presented with a line. (F) Average body mass of control and hypothyroid newborn rats. H\&E, bar $20 \mu \mathrm{m}$. Levels of significance: $* P<0.05$; ** $P<0.01$. Mean \pm SEM.

\section{Light microscopy:}

\section{Hypothyroidism in pups increases the number of altered oogonia/oocytes}

In both groups of newborn rats the boundaries between the presumptive medulla and cortex were not clearly defined and the dominant ovarian structures were GCN composed of oogonia/oocytes strings bounded by bands of stromal cells. Those that were localized below the surface epithelium in their basal and lateral parts were bordered by stromal cells but without a clear boundary in the part facing the surface of the ovary, so oogonia/oocytes were in direct contact with the surface epithelium and 
were mainly populated with resting oogonia and those undergoing mitosis (Figure 2-A and B). GCN in the central part of the ovaries were completely surrounded by stromal cells and within them oocytes in prediplotene and diplotene were dominant in both groups. In this part of the ovary, in both groups, individual flattened stromal cells (i.e. pre-granulosa) were identified (Figure 2-A and B). Also, in hypothyroid animals, a large number of oogonia/oocytes with highly eosinofilic cytoplasm were noticed (Figure 2B). Oogonia/oocytes in the GCN of the presumptive cortex appeared less compact
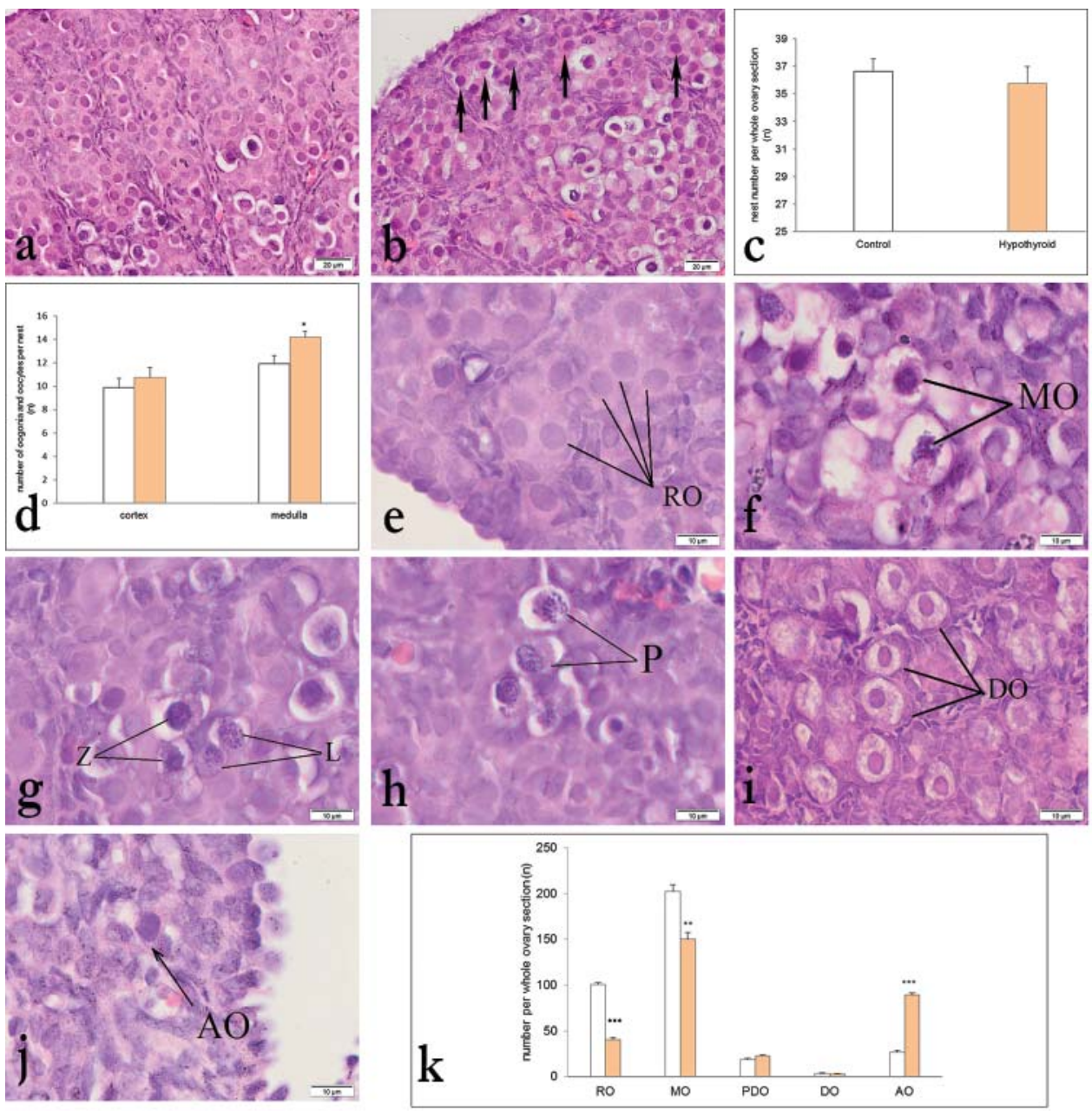

Figure 2. Ovary of newborn rats: (A) control and (B) hypothyroid (arrows pointing cells with eosinophilic cytoplasm). (C) Nest number per section in both groups. (D) Number of oogonia/ oocytes per nest in presumptive cortex and medulla in both groups. (E) Resting oogonia (RO). (F) Oogonia undergoing mitosis (MO). ( $\mathbf{G}$ and $\mathbf{H})$ Pre-diplotene oocytes (PDO). (I) Oocytes in diplotene (DO). (J) Atypical oogonia/oocyte with prominent vacuolization and acidophilic cytoplasm and/or condensed nucleus (AO). Arrow points clear vacuole in the cytoplasm of altered oocytes. L-oocyte in leptotene, Z-oocyte in zygotene, P-oocyte in pachytene. (K) Number of RO, MO, PDO, DO, AO. Open bars, control group; colored bars, hypothyroid. H\&E, bar $20 \mu \mathrm{m}$. Levels of significance: $* P<0.05$; $* * P<0.01$; $* * P<0.001$. Mean \pm SEM. 
in the hypothyroid group compared to the control (Figure 2-B). Number of GCN per section was not different between groups (Figure 2-C). Number of oogonia/ oocytes per GCN in the presumptive cortex was almost the same, and in the medulla was increased in hypothyroid rats (Figure 2-D).

Seven morphological types of oogonia/oocytes were defined (Figure 2-E, F, G, H, I, J). Among them, the number of resting and oogonia undergoing mitosis was decreased, the number of pre-diplotene and diplotene oocytes was not changed, but the number of altered oogonia/oocytes was increased in the ovaries of hypothyroid newborn rats (Figure 2-K).

\section{Electron microscopy: \\ Ovaries of hypothyroid pups have an increased number of $Z$ cells, oogonia/oocytes in apoptosis and in advanced process of autophagy}

In both groups some of the oogonia/oocytes were closely attached to each other and to the pre-granulosa cells (Figure 3-A) while altered oogonia/oocytes were without tight connection to surrounding cells (Figure 3-A and B). The number of degenerated and altered oogonia/oocytes was increased in the hypothyroid group (Figure 3-B).

Ultrastructural observations revealed the presence of four types of altered cells in GCN of both groups.

1. Degenerated pachytene oocytes (Z-cells) - these cells were previously described [14,15] (Figure 3-C).

2. Oogonia/oocyte undergoing autophagy - condensation of the chromatin was not detected and the cell membrane was well preserved. Accumulation of autophagic vacuoles was detected in the initial (formation of autophagosomes), intermediate (multivesicular bodies) and advanced (clear vesicles) stage. Numerous multilamellar bodies were present (Figure 3-D).

3. Oogonia/oocyte undergoing combined apoptosis and autophagy - with oval, pyknotic nucleus and membrane blebbing as morphological features of apoptosis. Heavily vacuolated cytoplasm was observed as an advanced autophagy sign (Figure 3-E).

4. Oogonia/oocyte undergoing apoptosis - cells with early signs of apoptosis were observed, with intensive nucleolar chromatin condensation and membrane blebbing (Figure 3-F). Some osmiophilic granules were detected in the cytoplasm of oogonia/oocytes, as well as in the surrounding stroma of ovaries of both groups (Figure 3-B and F).

A common finding in both groups was engulfment of Z-cells by surrounding pregranulosa cells (Figure 3-G). In most of the GCN of the hypothyroid group, oogonia/ oocytes were separated by morphologically homogeneous light material that mostly resembled the one found in late stages of degradation in autophagolysosomes (Figure 3-H). 
When different types of cells were enumerated the results were as follows: morphologically normal oogonia/oocytes were the most common in both groups; in the hypothyroid group, among altered oogonia/oocytes, the most numerous were Z-cells and those undergoing the advanced process of autophagy (Figure 3-I); apoptotic oogonia/oocytes were rare in both groups (Figure 3-I).

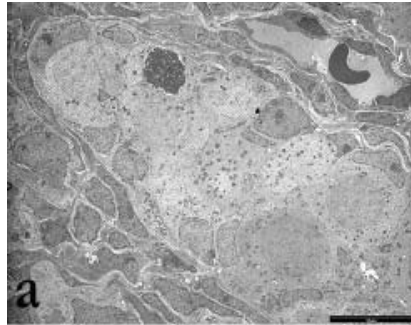

Germ cell nest - control

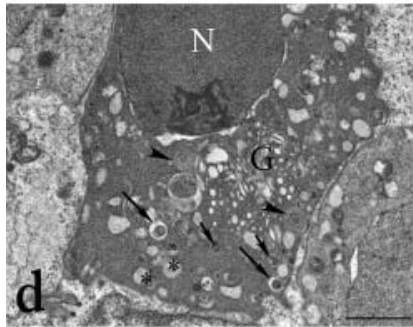

Oogonia/oocyte in autophagy

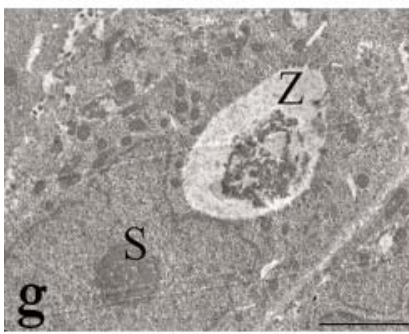

Phagocytosis of $\mathbf{Z}$ - cell

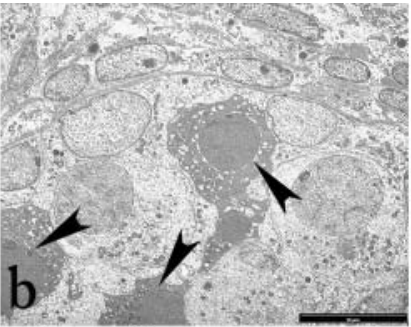

Germ cell nest - hypothyroid

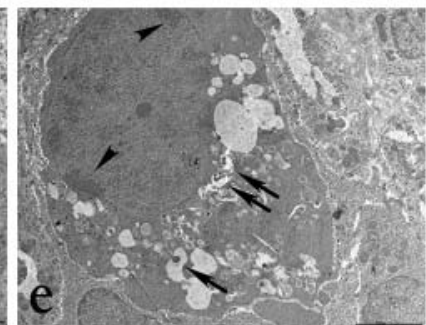

Apoptosis/autophagy

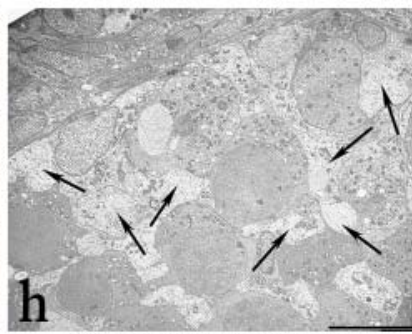

Clear material between oogonia/ooocytes

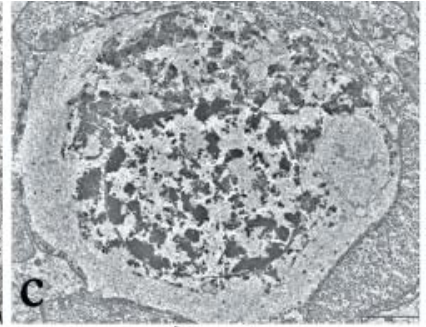

$\mathrm{Z}$ - cell

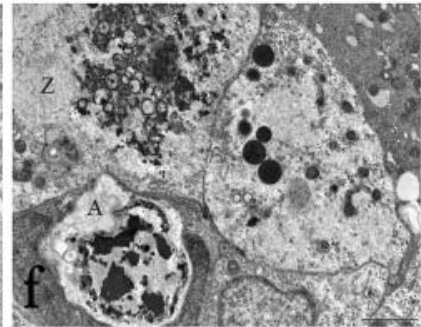

$\mathrm{Z}$ - cell and apoptosis

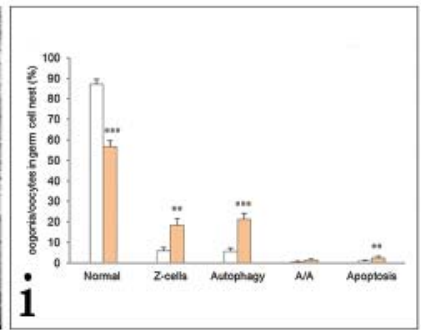

1 Figure 3. Germ cell nest in newborn rats: (A) control and (B) hypothyroid (arrowheads
pointing altered oogonia/oocytes). (C) Z-cell. (D) Ooogonia/oocyte in autophagy, N-nucleus, G-Golgi apparatus, multilamellar bodies (arrowheads), various autophagic profiles (long arrows - autophagosomes, short arrows - multivesicular bodies, asterisks - clear vesicles). (E) Oogonia/ oocyte undergoing combined cell death (apoptosis-autophagy). Arrowheads pointing nuclear shrinkage and peripheral condensation, slight blebbing of membrane and heavily vacuolized cytoplasm, with numerous autophagosomes (arrows). (F) Z-cell (Z) and apoptotic oocyte (A). (G) Z-cell (Z) engulfed by somatic cell (S). (H) Nest of the ovary of hypothyroid newborn rats with clear homogenous material between oogonia/oocytes (arrows). (I) Number of oogonia/ oocytes having a normal and altered morphology and different types of cell death in the ovaries of control and hypothyroid newborn rats. A/A - combined apoptosis/autophagy. Bar $10 \mu \mathrm{m}$ for A, B and I, $2 \mu \mathrm{m}$ for C, D, E, F, G. Levels of significance: ${ }^{* *} \mathrm{p}<0.01$; ${ }^{* * *} \mathrm{p}<0.001$. Mean \pm SEM. 


\section{TUNEL expression was decreased in hypothyroid pups while caspase-3, ATG7 and LC3 expression were similar in both groups}

TUNEL positive oogonia/oocytes were frequent in the presumptive medulla in the ovaries of control animals while in hypothyroid newborn rats were rare and randomly dispersed in both presumptive cortex and medulla (Figure 4-AB). Intense TUNEL expression was observed in the surface epithelium and partially in interstitial cells in both groups (Figure 4-AB). The number of TUNEL positive oogonia/oocytes was three times lower in comparison to the control (Figure 4C). In both groups of animals, caspase-3 positive oogonia/oocytes were rarely present (Figure 4-D and E) while ATG7 and LC3 were detectable in all oogonia/oocytes and expressed in their cytoplasm (Figure 4-EFGH).

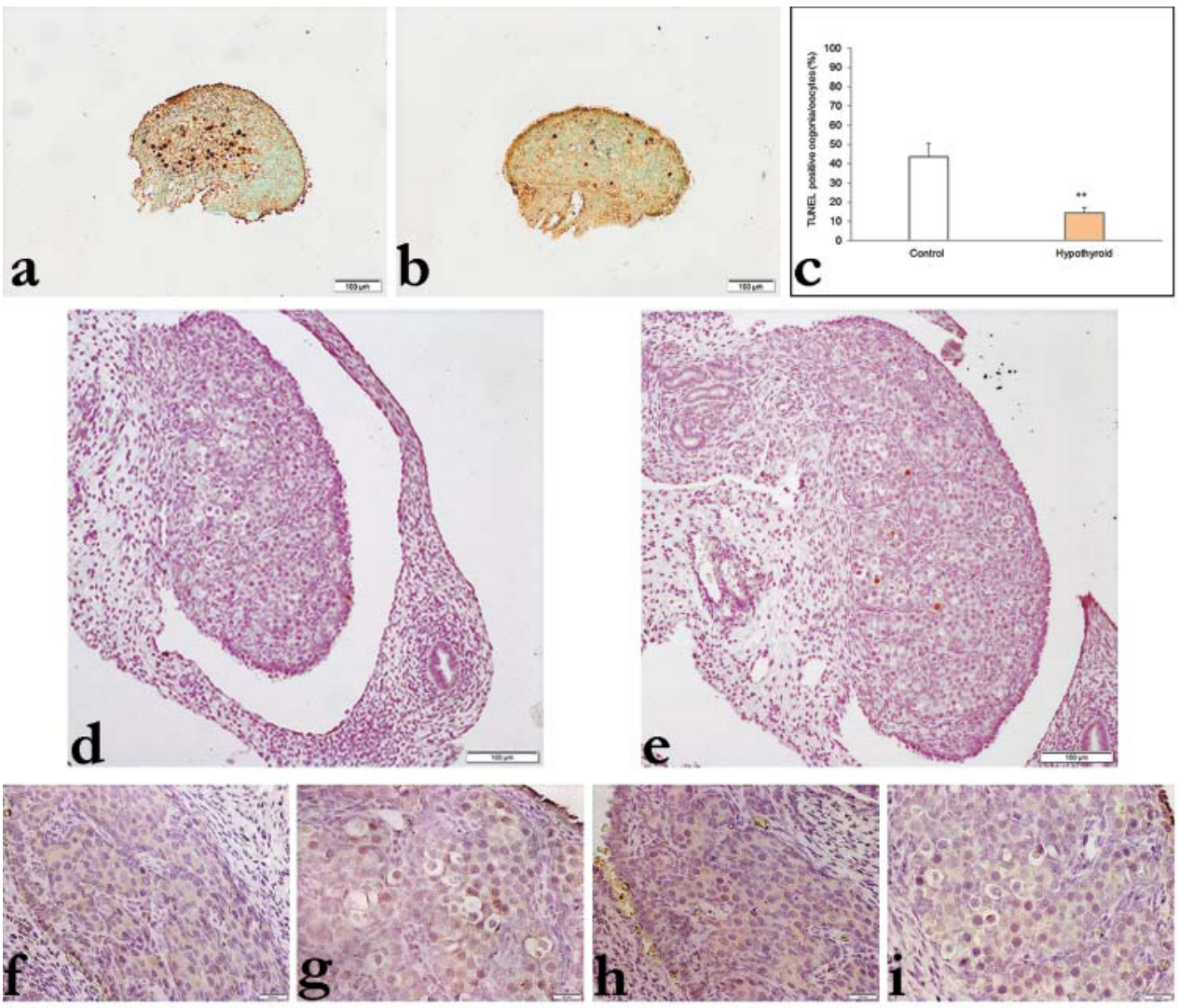

Figure 4. TUNEL expression in ovary of newborn rats (A) control and (B) hypothyroid. (C) Percentage of TUNEL positive oogonia/oocyte per whole ovary section of control and hypothyroid rats. Caspase-3 expression in the ovary of newborn rats: (D) control and (E) hypothyroid. ATG7 expression in ovary of newborn rats: (F) control and (G) hypothyroid. LC3 expression in the ovary of newborn rats: $(\mathbf{H})$ control and $(\mathbf{I})$ hypothyroid rat. Counterstain: hematoxylin for all except TUNEL (methyl green). Bar $100 \mu \mathrm{m}$ for A, B, C, D, E and $20 \mu \mathrm{m}$ for F, G, H and I. Level of significance: $* * \mathrm{P}<0.01$. Mean \pm SEM. 


\section{DISCUSSION}

This is the first study to demonstrate the influence of maternal hypothyroidism on ovarian tissue and oogonia/oocyte morphology features in the first 24 hours after birth in the hypothyroid rat pups. These ovaries had a high number of altered oogonia/ oocytes with cytoplasmic eosinophilia. Using electron microscopy, high number of Z-cells was identified and altered oogonia/oocytes were defined as degenerated due to the advanced process of autophagy, apoptosis or the combination of both. More oogonia/oocytes were TUNEL positive in the ovarian medulla in the control than in the hypothyroid group of animals while expression of caspase-3, ATG7 and LC3 was the same between groups.

In our system model, offspring's hypothyroidism was a consequence of maternal's one and was clinically marked with their lower body weight. Confirmation of offspring hypothyroidism was obtained through lower level of T3 and T4 and high thyroid activation index which showed that the increased TSH concentration was due to the physiological negative feedback as a response to the decreased thyroid hormones concentration.

In analyzed hypothyroid animals, the number of resting and mitotic oogonia was reduced and the number of altered oogonia/oocytes was increased. Indeed, with TEM analysis even a higher number of altered oogonia/oocytes have been recognized. Most of them were in the process of advanced autophagy or were recognized as degenerated Z-cells that were often being removed by phagocytosis. Early studies in normal mice and rats indicated the existence of Z-cells, defined as degenerated pachytene oocytes $[14,15]$. The nomenclature committee on cell death recommended that morphologically, three main types of cell death could be recognized: apoptosis, autophagy and necrosis but left the space for the existence of their combination in a plastic way [16]. As one such event, secondary necrosis was recognized to share morphological features with apoptosis and necrosis. Namely, apoptosis is characterized by hyper-condensed chromatin and nuclear fragmentation and necrosis with cytoplasm membrane rupture and release of cytoplasmic components [17]. Based on this, we could argue that Z-cells are in fact cells subjected to the process of secondary necrosis as they share both characteristics. Moreover, it was demonstrated that cells in a process of secondary necrosis could be phagocyted by different scavenger cells [17] that in the context of ovaries would be the pre-granulosa cells. Z-cells were rarely investigated and the only two articles (except the seminal ones from before fifty years ago) were those describing an increased number of Z-cells in Turner Syndrome in mice and humans $[7,18]$. Interestingly, it was demonstrated that hypothyroidism is common in Turner Syndrome [19]. Based on the stated facts we can suppose that during neonatal hypothyroidism the process of apoptosis could be diverted to necrosis. Z-cells could also accumulate due to the incapability of few pre-granulosa cells to engulf and destroy them in order to clear the space for normally developing oocytes. 
Although the number of apoptotic oogonia/oocytes observed on TEM was higher in hypothyroid animals, their number was low when related to the number of those undergoing the advanced process of autophagy and Z-cells. Also, the ratio between apoptosis and autophagy oogonia/oocyte that may lead to cell death was inverse in this study (for the control and hypothyroidism) when compared to those published previously for "normal" animals [20]. It is possible to hypothesize that the majority of cells that started the apoptotic pathway switched into necrosis forming Z-cells. Indeed, the only result supporting the dominance of apoptotic cell death is that TUNEL positive oogonia/oocytes were numerous in the medulla of the control animals, but this result should be discussed. As caspase-3 was not different between the groups, the caspase independent, TUNEL positive cell death pathway could be proposed, as demonstrated previously [21]. This scenario would argue for the relatively high number of TUNEL positive cells in control animals. On the other hand, although the TUNEL assay is widely used for apoptosis detection in the ovary, some authors state that exactly this marker is not reliable enough in the circumstances when meiosis is abundantly present [10]. Namely, this type of cell division is followed with intensive DNA reparatory processes and appearance of DNA fragments in single and double strand breaks. Considering the fact that TUNEL labels exactly these DNA fragments [22] the increased number of TUNEL positive oogonia/oocytes in our control group could indicate the greater extent of DNA repair mechanisms. Interestingly, De Felici [23] noticed that TUNEL positive fetal oocytes appeared morphologically healthy and this could be explained by the mechanism of DNA repair/RNA synthesis [24]. Indeed, our own results concerning the detection of apoptotic cells on TEM revealed apoptosis as a rare event. The final conclusion on the issue of abundance of TUNEL positive cells in the medulla of control animals could not be done and more detailed analysis should be performed. On the other side, light and electron microscopy gave good evidence of increased oogonia/oocyte degeneration and death in hypothyroid animals versus controls.

Though cells during the death process may show typical signs of autophagy, they are rarely eliminated by autophagic cell death [25] and low level of autophagy is a protective mechanism especially when cell starvation is induced [25]. Autophagic cell death has been reported in cancer cells, induced by histone deacetylase inhibitors [26] and in cells genetically engineered to lack some of the apoptosis/autophagy regulatory pathways [27]. However, autophagic and apoptotic cell death, as well as their combination are engaged in the elimination of degenerated nurse cells in the Drosophila virilis ovary [28] and prepubertal rat oocytes in vitro [20]. Based on previous data, one possible outcome of advanced autophagy could be the oogonia/oocyte death. Also, in our experiment, autophagic cell death could be related to disintegrated cell remnants visible between oogonia/oocytes and pregranulosa cells in GCN. These cell remnants can mimic apparent light microscopy non cohesiveness of oogonia/ oocytes in the GCN of hypothyroid animals. As hypothyroidism is a state of negative 
energy balance, in theory, it could be speculated that adjacent cells use the material recycled during autophagic cell death leaving cell remnants for final phagocytosis.

Although ultrastructural analysis revealed that most of altered cells are in advanced autophagy or they were dying by combining autophagy and apoptosis, ATG7 and LC3 did not differ between groups. So, we could suggest that ATG7 and LC3 in our study could be interpreted as markers for the basal level of autophagy, i.e. the commonly recognized protective mechanism against starvation immediately after birth [11]. To clarify the apparently contradictory results of advanced autophagy (especially in hypothyroid animals) obtained with TEM analysis and equal expression of autophagy markers ATG7 and LC3 we should study the markers of autophagy that are expressed in more advanced stages of this process - like lysosomal-associated membrane protein 1 and 2 (LAMP1 and LAMP2) or acid phosphatase. Altogether, according to our results, a decreased level of thyroid hormones does not affect the basal process of autophagy, but is connected to the advanced process of oogonia/oocyte autophagy that leads to their morphological changes consistent with dying cells.

Conclusion: Our findings suggest that hypothyroid newborn rat pups have enhanced mitotic oogonia and meiotic oocytes elimination mainly through the formation of Z-cells and engagement of an advanced process of autophagy.

\section{Acknowledgements}

The authors would like to thank to Anita Lazarević and Maja Bogdanović for their technical assistance. The study was supported by Serbian Ministry for Science and Technology grants \# 175061.

\section{Authors' contributions}

JDL done the experimental part of the study and statistical analyses and made a substantial contribution to conception and design and analysis, acquisition and interpretation of data and was involved in drafting the manuscript. IM, TL and ZM carried out animal welfare, immunohistochemical studies and acquisition of data. AR defined a research theme. AR, MKF and AK were involved in drafting the manuscript and revising it critically for important intellectual content and have made a substantial contribution to conception and design and analysis and interpretation of data. All authors read and approved the final manuscript.

\section{Declaration of conflicting interests}

The author(s) declared no potential conflicts of interest with respect to the research, authorship, and/or publication of this article. 


\section{REFERENCES}

1. Abalovich M, Mitelberg L, Allami C, Gutierrez S, Alcaraz G, Otero P, Levalle O: Subclinical hypothyroidism and thyroid autoimmunity in women with infertility. Gynecol Endocrinol 2007, 23(5):279-283.

2. Kirovski D, Dodovski P, Savić Đ, Vujanac I, Prodanović R, Mirilović M, Sladojević Ž, Djordjević A: Placental Iodothyronine Deiodinases Expression in Pregnant Cows Exposed to Propylthiouracil (Ptu) and Thyroid Axis Activity of their Calves. Acta Vet-Beograd 2016, 66(1):61-75.

3. Radovanović A, Roksandić D, Šimić M, Marković D, Gledić D: Effects of induced maternal hypothyroidism on the ovarian development of offspring rats. Acta Vet-Beograd 2012, 62.

4. Danilović Luković J, Korać A, Milošević I, Lužajić T, Puškaš N, Kovačević Filipović M, Radovanović A: Altered state of primordial follicles in neonatal and early infantile rats due to maternal hypothyroidism: Light and electron microscopy approach. Micron 2016, 90:33-42.

5. Gosden RG, Faddy MJ: Biological bases of premature ovarian failure. Reprod Fertil Dev 1998, 10:73-78.

6. Vázquez-Nin GH, Escobar ML, De Felici M, Echeverría OM, Klinger FG: Cell Death in Mammalian Ovary. London, United Kingdom: Springer Science \& Business Media; 2011.

7. Burgoyne PS, Baker TG: Perinatal oocyte loss in XO mice and its implications for the aetiology of gonadal dysgenesis in XO women. J Reprod Fertil 1985, 75: 633-645.

8. Di Giacomo M, Barchi M, Baudat M, Edelman W, Keeney S, Jasin M: Distinct DNAdamage-dependent and -independent responses drive the loss of oocytes in recombinationdefective mouse mutants. Proc Natl Acad Sci USA 2005, 102:737-742.

9. Escobar ML, Echeverria OM, Ortiz R, Vasquez-Nin GH: Combined apoptosis and autophagy, the process that eliminates the oocytes of atretic follicles in immature rats. Apoptosis 2008, 13:1253-1266.

10. Ghafari F, Gutierrez CG, Hartshorne GM: Apoptosis in mouse fetal and neonatal oocytes during meiotic prophase one. BMC Dev Biol 2007, 7:87.

11. Gawriluk TR, Hale AN, Flaws JA, Dillon CP, Green DR, Rucker EB: Autophagy is a cell survival program for female germ cells in the murine ovary. Reproduction 2011, 141:759765.

12. Inserra PI, Leopardo NP, Willis MA, Freysselinard AL, Vitullo AD: Quantification of healthy and atretic germ cells and follicles in the developing and post-natal ovary of the South American plains vizcacha, Lagostomus maximus: evidence of continuous rise of the germinal reserve. Reproduction 2014, 147:199-209.

13. Roksandić D, Radovanović A, Danilović Luković J, Marković D, Kovačević Filipović M, Čolić M: Stereological and Immunohistochemical Study of the Spleen in Hypothyroid Juvenile Rats. Acta Vet-Beograd 2015, 65(2):246-259.

14. Baker TG, Franchi LL: The Fine Structure of Oogonia and Oocytes in Human Ovaries. J Cell Sci 1967, 2:213-224

15. Franchi LL, Mandl AM: The Ultrastructure of Oogonia and Oocytes in the Foetal and Neonatal Rat. Proc R Soc Lond B Biol Sci 1962, 157:99-114.

16. Kroemer G, Galluzzi L, Vandenabeele P, Abrams J, Alnemri ES, Baehrecke EH, Blagosklonny MV, El-Deiry WS, Golstein P, Green DR, Hengarner M, Knight RA, Kumar S, Lipton SA, Malorni W, Nunez G, Peter ME, Tschopp J, Yuan J, Piacentini M, Zhivotovsky B, Melino 
G: Classification of cell death: recommendations of the Nomenclature Committee on Cell Death. Cell Death Differ 2009, 16:3-11.

17. Silva MT: Secondary necrosis: the natural outcome of the complete apoptotic program. FEBS lett 210, 584:4491-4499.

18. Speed R: Oocyte development in XO foetuses of man and mouse: the possible role of heterologous X-chromosome pairing in germ cell survival. Chromosoma 1986, 94:115-124.

19. El-Mansoury M, Bryman I, Berntorp K, Hanson C, Wilhelmsen L, Landin-Wilhelmsen $\mathrm{K}$ : Hypothyroidism is common in turner syndrome: results of a five-year follow-up. J Clin Endocrinol Metab 2005, 90:2131-2135.

20. Escobar ML, Echeverria OM, Sanchez-Sanchez L, Mendez C, Pedernera E, VasquezNin GH: Analysis of different cell death processes of prepubertal rat oocytes in vitro. Apoptosis 2010, 15: 511-526.

21. Lobascio AM, Kliger FG, Scaldaferri ML, Farini D, De Felici M: Analysis of programmed cell death in mouse fetal oocytes. Reproduction 2007, 134:241-252.

22. Kumari S, Rastogi RP, Singh KL, Singh SP, Sinha RP: DNA damage: detection strategies. EXCLI Journal 2008, 7:44-62.

23. De Felici M, Lobascio AM, Klinger FG: Cell death in fetal oocytes: Many players for multiple pathways. Autophagy 2008, 4:240-242.

24. Kockx MM, Muhring J, Knaapen MW, de Meyer GR: RNA synthesis and splicing interferes with DNA in situ end labeling techniques used to detect apoptosis. Am J Pathol 1998, 152:885-888.

25. Kroemer G, Levine B: Autophagic cell death: the story of a misnomer. Nat Rev Mol Cell Biol 2008, 9:1004-1010.

26. Shao Y, Gao Z, Marks PA, Jiang X: Apoptotic and autophagic cell death induced by histone deacetylase inhibitors. Proc Natl Acad Sci 2004, 101(52):18030-18035.

27. Shimizu S, Kanaseki T, Mizushima N, Mizuta T, Arakawa-Kobayashi S, Thompson CB, Tsujimoto Y: Role of Bcl-2 family proteins in a non-apoptotic programmed cell death dependent on autophagy genes. Nat Cell Biol 2004, 6(12):1221-1228.

28. Velentzas AD, Nezis IP, Stravopodis DJ, Papassideri IS, Margaritis LH: Apoptosis and autophagy function cooperatively for the efficacious execution of programmed nurse cell death during Drosophila virilis oogenesis. Autophagy 2007, 3:130-132.

\section{Z ĆELIJE I OOGONIJE/OOCITE U UZNAPREDOVALOJ AUTOFAGIJI SU NAJZASTUPLJENIJI TIP IZMENJENIH ĆELIJA U JAJNICIMA HIPOTIREOIDNIH NOVOROĐENIH PACOVA}

DANILOVIĆ LUKOVIĆ Jelena, KORAĆ Aleksandra, MILOŠEVIĆ Ivan, LUŽAJIĆ Tijana, MILANOVIĆ Zorana, KOVAČEVIĆ FILIPOVIĆ Milica, RADOVANOVIĆ Anita

Hipotireoidizam eksperimentalno izazvan u toku prenatalnog razvoja kod pacova ima za posledicu ubrzano sazrevanje primordijalnih folikula udruženo sa atrezijom folikula, što dovodi do poremećaja funkcije jajnika. Ovo istraživanje imalo za cilj da 
ispita uticaj hipotireoidizma majki indukovanog 6-n-propil-2-tiouracilom na broj i morfologiju oogonija/oocita tokom mitoze i rane profaze mejoze I kod novorođenih pacova upotrebom svetlosne i elektronske mikroskopije. Ekspresija markera apoptoze i autofagije u oogonijama/oocitama utvrđena je imunohistohemijski. Hipotireoidni pacovi su imali smanjen broj mirujućih i oogonija u mitozi dok je broj izmenjenih oogonija/oocita bio povećan. Ultrastrukturnom analizom je utvrđeno prisustvo degenerisanih oocita u pahitenu (Z-ćelije) kao i oogonija/oocita u autofagiji, apoptozi i kombinaciji ova dva tipa ćelijske smrti kod ove grupe. Najveći broj izmenjenih ćelija kod hipotireoidne grupe su bile Z-ćelije i oogonije/oocite izmenjenih uznapredovalim procesom autofagije. Procenat TUNEL pozitivnih oogonija/oocita je bio značajno manji kod hipotireoidne grupe. Nije zabeležena značajna razlika u ekspresiji kaspaze-3, ATG7 i LC3. Dobijeni rezultati ukazuju da prenatalni hipotireoidizam kod potomaka dovodi do nastanka većeg broja Z-ćelija i oogonija/oocita izmenjenih uznapredovalim procesom autofagije. 